\title{
Dental Age Estimation Methods in Egyptian Studies: Systematic Review
}

\author{
Amal A El-Bakary
}

\begin{tabular}{|c|c|}
\hline & ABSTRACT \\
\hline $\begin{array}{l}\text { KEYWORDS } \\
\text { Dental age, } \\
\text { Egyptians, } \\
\text { Pulp/Tooth Area Ratio, } \\
\text { Demirjian method, } \\
\text { Forensic odontology }\end{array}$ & $\begin{array}{l}\text { Age estimation is fundamental in personal identification, especially in cases } \\
\text { undergoing criminal proceedings, immigrants, or those requesting asylum. Variation } \\
\text { in dental development among populations is reported in the literature without clear } \\
\text { explanations. In the absence of population-specific standards, data from other } \\
\text { populations will be used as a reference without considering whether they are } \\
\text { appropriate or not. The main objective of dental age estimation methods is to obtain } \\
\text { the best-standardized method for legal age estimation. Hence, age estimation } \\
\text { methods must be simple, reliable, and can be applied to both living and dead } \\
\text { individuals. In this document, I tried to shed light on the published Egyptian studies } \\
\text { discussing different methods for dental age estimation. Unfortunately, a little number } \\
\text { of Egyptian studies could be found in this field. Eight dental age estimation methods } \\
\text { were reported in } 19 \text { Egyptian studies. The commonest evaluated method was the } \\
\text { Pulp/Tooth Area Ratio ( } 5 \text { studies) followed by that of Demirjian et al. (1973) (4 } \\
\text { studies). It is recommended to adopt the idea of establishing a validated Egyptian } \\
\text { study that introduces Egyptian- specific standards. }\end{array}$ \\
\hline
\end{tabular}

\section{Introduction}

Age is a very important cultural, religious, and social matter (Chudasama et al., 2012). From the forensic point of view, age estimation is the cornerstone in the identification of unknown bodies and skeletal remains (Willems et al., 2002). Indicators used for age assessment are usually those related to somatic, sexual, skeletal, and dental maturity (Schmeling et al., 2004). From these methods, teeth provide several reliable parameters for age prediction (Wahdan et al., 2017).

\footnotetext{
${ }^{(I)}$ Forensic Medicine and Clinical Toxicology, Mansoura University, Egypt.
}

As age estimation is a challenging task, the main objective is to obtain the beststandardized method for both legal and medical age estimation. Thus, it must be simple, reproductive, and can be applied both ante- and post-mortem (Jayaraman et al., 2011).

The first published scientific study that proved the use of teeth as an age indicator was presented in 1837 by Edwin Saunders (Stavrianos et al., 2008). Later, several techniques have been introduced for dental age estimation. Methods can be divided into four main categories: clinical (visual), morpho-histological, biochemical, and radiological methods. The clinical (visual) method depends on the eruption of teeth. The age at which the teeth erupt, is greatly related 
to the growth and development of the child (Alnemer et al., 2017).

Morpho-histological methods are based on the assessment of dental regressive changes microscopically thus require extracted teeth e.g. Gustafson (1950). In this method, each of the criteria has a score ranging from 0 to 3 . The grade value of each age change is then added to give a total score. The error of age estimation was \pm 3.6 years. However, these methods are not acceptable due to ethical, religious, and scientific reasons.

The biochemical method depends on the racemization of amino acids. L-aspartic acids are converted, in a time-dependent manner, to D-aspartic acids. So, the levels of D-aspartic acid in enamel, dentin, and cementum could be correlated with age (Stavrianos et al., 2008).

Radiographic assessment of age is a non-invasive, simple, and reproducible method that can be employed for both living and dead bodies. These methods depend on the assessment of teeth mineralization and development stages. Various radiographic images were used in age identification as panoramic, peri-apical, cephalometric, and lateral oblique radiographs in addition to advanced imaging technologies (Panchbhai, 2011).

The chart (atlas) introduced by Schour and Massler (1941) was the 1st attempt at scientific dental age estimation that is based on a survey. The chart is based on direct comparisons with radiographs. They gave twenty stages of teeth development from four months in utero to 21 years of age. There were no separate surveys for males or females.

In Nolla's method (1960), the mineralization of permanent dentition was divided into ten stages. Each tooth is given a reading and a total is made that is compared with a table provided. Girls and boys are dealt with separately.

Demirjian et al. (1973), a widely used method, is based on the development of the seven left permanent mandibular teeth that are divided into eight stages from the beginning of calcification to the final mature form. Each tooth has a stage that can be converted into a sex-specific maturity score. The sum of the scores provides an estimate of the subject's dental maturity, measured on a scale from 0 to 100. In 1993, Mincer et al. modified Demirjian et al. (1973) method by including the 3rd molar in the maturation score. Regression formulas and empirical probabilities were provided.

Willems et al. (2001) also made some modifications to Demirjian's method. Developmental stages described in Demirjian's technique were expressed directly in years for each of the seven left mandibular teeth for boys and girls. All scores are summed up to give dental age in years directly using the reference tables.

Other methods assessed the volume of teeth in correlation to age. Ikeda et al. (1985) calculated the tooth coronal index (TCI) by measuring the coronal pulp cavity length and tooth crown length on the radiographs of incisors and molars. Meanwhile, Kvaal et al. (1995) used the pulp-to-tooth ratio as an indicator of age. This method depends on the fact that secondary dentin deposition, by aging, reduces the size of the dental pulp cavity. By applying linear regression analysis, the measurement of this reduction was correlated with age.

After the ages of 15, the maturity of the third molar is one of the few quantitative biological indicators used for age estimation. Harris and Nortje (1984) suggested five stages for root development in the third molars that were correlated with age. 
Several articles have been published describing the use of three-dimensional imaging techniques in dental age estimation methods. These include: Computed Tomography (CT) came in 1972, Micro Computed Tomography (Micro-CT) in the early 1980s, Magnetic Resonance (MR) came in 1985 and Cone-Bean Computed Tomography (CBCT) in 1996 (Bjørk and Kvaal, 2018). Also, automatic software was developed that uses referable morphological and radiological techniques (Willems, 2000).

Another principle used open apices for age estimation is the Cameriere method (2006). The distance of open apices was correlated with age through a linear regression formula. The ratio of the height of teeth and the width of their 'open' apex is measured; this allows compensating magnification and angulation errors induced during radiography.

In 2008, Cameriere et al. applied the third molar maturity index (I3M) as an indication of the age of 18 years. The I3M depends on the measurement of the width of the open apices of the mandibular third molars. A threshold (cutoff) value of I3M was identified discriminating adults from the minors.

In this review, I tried to put my hands on most of the published Egyptian studies discussing different methods for dental age estimation. This can help to find the gaps, problems, and advantages which can lead us to further research.

\section{Methods}

A literature search of PubMed, Google, Google Scholar, Egyptian Knowledge Bank, and Research Gate databases was conducted to identify all eligible published studies discussing dental age estimation in Egyptians. Keywords were age estimation, dental age, and Egyptian. Criteria for the selection were restricted to original articles, published in English and on the Egyptians. The articles discussing sex identification from teeth were excluded. The articles were analyzed and the characteristics of each article were systemized to give a short overview of the main points.

\section{Results}

Nineteen articles were retrieved through electronic search using the chosen keywords. Two studies were excluded as age estimation was through mandibular indices. Table (1) illustrates that the evaluated methods were Pulp/Tooth Area Ratio (5 articles), Demirjian et al. (1973) method (4 articles), coronal index (2 articles), the emergence of teeth (2 articles), cemental incremental lines (one study) and the third molar maturity index (one study). Meanwhile, two studies were comparative. 
Table (1): Characteristics of Egyptian studies for dental aging

\begin{tabular}{|c|c|c|c|}
\hline Methods & Reference articles & Study sample & Age of subjects \\
\hline \multirow{2}{*}{$\begin{array}{l}\text { 1. Emergence of } \\
\text { teeth }\end{array}$} & Soliman et al. (2011) & $\begin{array}{l}1132 \text { infants } \\
\text { Selected from different governorates of } \\
\text { Egypt }\end{array}$ & 4-36 months \\
\hline & Elhiny et al. (2018) & $\begin{array}{l}978 \text { children } \\
\text { Fayoum Governorate (to the west of } \\
\text { Cairo) }\end{array}$ & $6-12$ years \\
\hline \multirow{4}{*}{$\begin{array}{l}\text { 2. Demirjian } \\
\text { method }\end{array}$} & $\begin{array}{l}\text { Hassan and Abo Hamila } \\
\text { (2007) }\end{array}$ & $\begin{array}{l}380 \text { ( } 214 \text { males and } 166 \text { females }) \text { from } \\
\text { the middle Delta region. }\end{array}$ & 8 - 26 years \\
\hline & Azzawi et al. (2016) & $\begin{array}{l}400 \text { children from Tanta City (the middle } \\
\text { Delta region) }\end{array}$ & $5-13$ years \\
\hline & Ali et al. (2019) & $\begin{array}{l}160 \text { children from Minia Governorate, } \\
\text { Upper Egypt }\end{array}$ & $3-10$ years \\
\hline & El-Shenawy et al. $(20) \varepsilon)$ & 200 children from Cairo & $8-10$ years \\
\hline \multirow[t]{2}{*}{ 3. Coronal index } & El Morsi et al. (2015) & $\begin{array}{l}234 \text { subjects ( } 119 \text { males and } 115 \text { females) } \\
\text { Mansoura City, from the middle Delta } \\
\text { region. }\end{array}$ & $8-74$ years \\
\hline & Wahdan et al. (2017) & $\begin{array}{l}170 \text { Egyptians, Tanta City, from the } \\
\text { middle Delta region. }\end{array}$ & --- \\
\hline \multirow{5}{*}{$\begin{array}{l}\text { 4. Pulp/Tooth } \\
\text { Area Ratio } \\
\text { (PTR) }\end{array}$} & Ahmed et al. (2013) & $\begin{array}{l}48 \text { cases; } 24 \text { males and } 24 \text { females, } \\
\text { (CBCT). } \\
\text { Minia Governorate, Upper Egypt }\end{array}$ & $14-45$ years \\
\hline & Abd El-Wahab et al. (2013) & $\begin{array}{l}600 \text { digital orthopantomogram, from } \\
\text { Cairo. }\end{array}$ & --- \\
\hline & Afify et al. (2014) & $\begin{array}{l}500 \text { panoramic radiographs ( } 262 \text { males } \\
\text { and } 238 \text { females), from Cairo }\end{array}$ & $18-71$ years \\
\hline & Elmoazen et al. (2017) & $\begin{array}{l}150 \text { individuals ( } 262 \text { males and } 238 \\
\text { females (CBCT) }\end{array}$ & $18-70$ years \\
\hline & Afify et al. (2019) & 150 individuals (CBCT) from Cairo & $14-68$ years \\
\hline $\begin{array}{l}\text { 5. The third molar } \\
\text { maturity index } \\
\left(\mathrm{I}_{3 \mathrm{M}}\right) \\
\end{array}$ & El-Bakary et al. (2019) & $\begin{array}{l}247 \text { orthopantography ( } 97 \text { boys and } 150 \\
\text { girls), Mansoura City, from the middle } \\
\text { Delta region. }\end{array}$ & $13-24$ years \\
\hline \multirow{2}{*}{$\begin{array}{l}\text { 6. Comparative } \\
\text { studies }\end{array}$} & El-Bakary et al. (2010) & $\begin{array}{l}286 \text { panoramic radiographs ( } 134 \text { boys, } \\
152 \text { girls), Mansoura City, from the } \\
\text { middle Delta region. }\end{array}$ & $5-16$ years \\
\hline & Rabie et al. (2018) & $\begin{array}{l}310 \text { panoramic radiographs ( } 183 \text { girls and } \\
127 \text { boys), Mansoura City, from the } \\
\text { middle Delta region. }\end{array}$ & $5-16$ years \\
\hline $\begin{array}{l}\text { 7. Cemental } \\
\text { Incremental } \\
\text { Lines }\end{array}$ & Hassan and Shehab (2004) & 82 mandibular first premolar teeth & --- \\
\hline
\end{tabular}

CBCT: cone-beam computerized tomography 


\section{Discussion}

This systematic review article emphasizes published research for dental age estimation in Egyptians. Two studies were reported discussing teeth emergence as a tool for age estimation in Egyptians. It was clear that the date of emergence of teeth is different from international values as shown in tables 2

and 3. This dissimilarity may be mainly attributed to the variation in race and ethnic background. The Egyptian population is rich in different ethnic backgrounds depending on the geographical location (Elhiny et al., 2018).

Table (2): Dental emergence times (mean \pm SD) of the left, right and both sides of dentition for the maxillary and mandibular arches (n: 1132), (Soliman et al., 2011).

\begin{tabular}{|c|c|c|c|c|c|c|}
\hline \multirow{3}{*}{ Tooth } & \multicolumn{6}{|c|}{ Age of teeth emergence (months) } \\
\hline & \multicolumn{3}{|c|}{ Boys } & \multicolumn{3}{|c|}{ Girls } \\
\hline & $\begin{array}{c}\text { Left side } \\
\text { mean (SD) }\end{array}$ & $\begin{array}{l}\text { Right side } \\
\text { mean (SD) }\end{array}$ & $\begin{array}{l}\text { Both sides } \\
\text { mean (SD) }\end{array}$ & $\begin{array}{c}\text { Left side } \\
\text { mean (SD) }\end{array}$ & $\begin{array}{l}\text { Right side } \\
\text { mean (SD) }\end{array}$ & $\begin{array}{l}\text { Both sides } \\
\text { mean (SD) }\end{array}$ \\
\hline \multicolumn{7}{|l|}{ Maxilla } \\
\hline Central incisor & $9.9(2.0)$ & $9.7(2.0)$ & $9.8(2.0)$ & $9.8(4.8)$ & $10.0(4.8)$ & $9.9(4.8)$ \\
\hline Lateral incisor & $11.6(3.4)$ & $12.3(4.1)$ & $12.0(3.8)$ & $13.1(5.1)$ & $13.3(4.9)$ & $13.2(5.0)$ \\
\hline Canine & $19.5(3.8)$ & $19.3(3.8)$ & $19.4(3.8)$ & $20.0(4.3)$ & $19.9(4.3)$ & $19.8(4.3)$ \\
\hline 1st deciduous molar & $17.2(3.8)$ & $17.0(3.6)$ & $17.1(3.7)$ & $17.2(4.4)$ & $16.8(4.5)$ & $17.0(4.5)$ \\
\hline 2nd deciduous molar & $25.5(2.3)$ & $25.2(3.6)$ & $25.4(3.0)$ & $27.8(4.9)$ & $29.9(6.3)$ & $28.9(5.6)$ \\
\hline \multicolumn{7}{|l|}{ Mandible } \\
\hline Central incisor & $7.9(2.0)$ & $8.1(2.1)$ & $8.0(2.1)$ & $7.9(5.2)$ & $7.8(5.5)$ & $7.9(5.4)$ \\
\hline Lateral incisor & $12.7(3.7)$ & $13.2(4.2)$ & $13.0(4.0)$ & $13.6(6.1)$ & $12.7(4.5)$ & $13.2(5.3)$ \\
\hline Canine & $20.4(4.5)$ & $20.2(4.4)$ & $20.3(4.5)$ & $19.8(4.2)$ & $19.3(4.1)$ & $19.6(4.2)$ \\
\hline 1st deciduous molar & $17.0(4.4)$ & $17.0(4.2)$ & $17.0(4.3)$ & $16.6(4.7)$ & $16.8(4.6)$ & $16.7(4.7)$ \\
\hline 2nd deciduous molar & $25.4(3.6)$ & 25.7 (3.6) & $25.6(3.6)$ & $29.9(6.3)$ & $26.3(5.0)$ & $28.1(5.7)$ \\
\hline
\end{tabular}

SD: standard deviations

Table (3): Means and standard deviations of emergence times of permanent teeth in years in both arches in a group of Egyptians in Fayoum governorate (n: 978), (Elhiny et al., 2018).

\begin{tabular}{|l|c|c|c|c|c|c|c|c|}
\hline \multirow{3}{*}{ Tooth } & \multicolumn{9}{|c|}{ Times of emergence } \\
\cline { 2 - 10 } & \multicolumn{4}{|c|}{ Lower } & \multicolumn{4}{c|}{ Upper } \\
\cline { 2 - 10 } & \multicolumn{2}{|c|}{ Males } & \multicolumn{2}{c|}{ Females } & \multicolumn{2}{c|}{ Males } & \multicolumn{2}{c|}{ Females } \\
\cline { 2 - 10 }$y$ & Mean & SD & Mean & SD & Mean & SD & Mean & SD \\
\hline Central Incisor & 7.01 & 1.48 & 6.65 & 1.61 & 7.42 & 1.48 & 7.35 & 1.88 \\
\hline Lateral Incisor & 7.34 & 1.57 & 7.56 & 1.58 & 8.11 & 1.66 & 8.25 & 1.71 \\
\hline Canine & 10,42 & 1.48 & 10.28 & 1.32 & 11.17 & 1.41 & 10.98 & 1.37 \\
\hline First Premolar & 10,18 & 1.90 & 10.36 & 1.44 & 10.67 & 1.39 & 10.25 & 1.26 \\
\hline Second Premolar & 11,03 & 1.35 & 11,96 & 1.31 & 10.74 & 1.61 & 10.66 & 1.29 \\
\hline First molar & 6.62 & 1.59 & 7.34 & 1.52 & 6.89 & 1.50 & 6.51 & 1.91 \\
\hline Second molar & 11.40 & 2.11 & 11.78 & 2.15 & 11.72 & 1.69 & 11.73 & 1.44 \\
\hline
\end{tabular}

SD: standard deviations 
Demirjian et al.'s (1973) method was evaluated by four studies on Egyptians. They showed an overestimation of age with different accuracy values between studies. These encouraged Ali et al. (2019) to generate a formula for the prediction of age using logistic regression analysis. While the coronal index was assessed by two studies, a regression equation was proposed by Wahdan et al. (2017) that utilized mandibular permanent $1^{\text {st }}$ molars TCI. Meanwhile, E1 Morsi et al. (2015) proposed a regression equation relating $2^{\text {nd }}$ right premolar tooth coronal index to age.

As for the pulp/tooth area ratio, the most accurate model for the determination of age was different between the reported five Egyptian studies. While, Ahmed et al. (2013) found that the most accurate model was the maxillary first premolar tooth; $\mathrm{r}=97 \%$ (compared to incisors and canine; $r=90 \%$ ), Afify et al. (2014) indicated that the mandibular $2^{\text {nd }}$ premolar $(\mathrm{r}=-0.947)$ (compared to canine $(\mathrm{r}=-0.941)$ and $1^{\text {st }}$ premolars $(\mathrm{r}=-0.914)$ ) was the most closely correlated with age. Differences in results may be related to the accuracy of the radiological technique used. Ahmed et al. (2013) used cone-beam computerized tomography while Afify et al. (2014) used panoramic radiographs. Also, differences in sample size may contribute to different results.

On the other hand, the third molar maturity index $\left(\mathbf{I}_{3 M}\right)$ proposed by Cameriere et al. (2008) was evaluated only by one study. The authors concluded that $\mathrm{I}_{3 \mathrm{M}}$ can discriminate between individuals who are $\geq$ 18 years and those under 18 with the proportion of correctly classified boys $97 \%$ while it was $59 \%$ only in girls (El-Bakary et al., 2019).
Only two comparative studies (ElBakary et al., 2010 and Rabie et al., 2018) were reported. Demirjian et al. (1973), Willems et al. (2001), and Cameriere et al. (2006) methods were compared. Willems et al. (2001) were the most accurate in both studies. While an overestimation of age in Demirjian's and Willem's methods was detected, an underestimation of age in Cameriere's method was observed.

Meanwhile, cemental incremental lines were evaluated in one study (Hassan and Shehab, 2004)) that showed an average error of more than 3 years.

Different results in evaluating the same method in the same ethnic group may be due to different and/or small sample sizes, different age groups, different radiological techniques used (panorama versus CT), and/or different statistical analytical methods. So, it is recommended to evaluate the reported most accurate studies in a large representative sample of Egyptians, suggesting formulae more appropriate for Egyptians and studying ages for teeth eruption standardized for Egyptians.

\section{References}

Abd El-Wahab, T.M.A.A.; Marzouk, A.M.A. and Khattab, N.A.F. (2013) 'An orthopantomographic study for age and sex estimation: a comparative study among Egyptians and Tunisians adults', Ph.D. Thesis, Cairo University, Egypt (Abstract).

Afify, M.M.; Salem, W. and Mahmoud N.F (2019) 'Age estimation from pulp/tooth area ratio of canines using cone-beam computed tomography image analysis: study of an Egyptian sample', J. Forensic Res., 10, p.434. DOI: $10.4172 / 2157-7145.1000434$ 
Afify, M.M.; Zayet, M.K.; Mahmoud N.F. and Ragab A.R. (2014) 'Age estimation from pulp/tooth area ratio in three mandibular teeth by panoramic radiographs: study of an Egyptian sample', J. Forensic Res., 5, p231. doi:10.4172/2157-7145.1000231

Ahmed, H.M.; Ewiss, A.A.; Khattab, N.M. and Amer, M.E. (2013) 'Age estimation through dental measurements using cone-beam computerized tomography images in a sample of upper Egyptian population', Ain Shams J. Forensic Med. Clin. Toxicol., (21), p75-88.

Ali, A.M.M.; Ahmed, W.H. and Khattab, N.M. (2019) 'Applicability of Demirjian's method for dental age estimation in a group of Egyptian children', BDJ Open, 5, p2. doi: 10.1038/s41405-019-0015-y

Alnemer, K.A.; Pani S.C.; Althubaiti A.M. and Bawazeer, M. (2017) 'Impact of birth characteristics, breast feeding and vital statistics on the emergence of primary teeth among healthy infants in Saudi Arabia: an observational study', BMJ Open, 15; 7(12), p e018621. doi: 10.1136

Azzawi, A.M.; El Hosary, A.M. and Ezzat, A.M. (2016) 'Dental age assessment among a group of children in Tanta city', Tanta Dental Journal, 13(2), p 89-95.

Bjørk M.B. and Kvaal, S.I. (2018) ' $\mathrm{CT}$ and MR imaging used in age estimation: A systematic review', J. Forensic Odontostomatol., 36(1), p 14-25.

Cameriere, R.; Ferrante, L. and Cingolani, M. (2006) 'Age estimation in children by measurement of open apices in teeth', Int. J. Legal Med., 120, p 49-52.
Cameriere, R.; Ferrante, L.; De Angelis, D.; at al. (2008) 'The comparison between measurement of open apices of third molars and Demirjian stages to test chronological age of over 18 year olds in living subjects', Int. J. Legal Med., 122(6), p493-497.

Chudasama, P.; Roberts, G. and Lucas, V. (2012) 'Dental age assessment: A study of a caucasian population at the 13 year threshold', Journal of Forensic and Legal Medicine, 19(1), p22-28.

Demirjian, A. (1973) 'A new system of dental age assessment', Human Biology, 45 (2), p211.

El-Bakary, A.A.; Hammad, S.M. and Mohammed, F. (2010) 'Dental age estimation in Egyptian children, comparison between two methods', $J$. Forensic Leg. Med., 17(7), p 363-367. doi: 10.1016/j.jflm.2010.05.008.

El-Bakary, A.A.; El-Azab, S.M.; Abou El Atta, H.M.; et al. (2019) 'Accuracy of the cutoff value of the third molar maturity index: an Egyptian study', Egypt. J. Forensic Sci., 9, p 52 https://doi.org/10.1186/s41935-0190156-0

Elhiny, O.A.; Sharaf, R.F.; Abou el Yazeed, M.; et al. (2018) 'Emergence of permanent teeth among a group of Egyptian children at Fayoum Governorate', Curr. Sci. Int., 7(4), p 814-817.

Elmoazen, R.; Salah Eldin, M.S. and Abd Alkhalek, W. (2017) 'Age estimation in an Egyptian population using pulp/tooth volume ratio obtained from cone beam computed tomography', E.D.J., 63(2), p1-9.

EI Morsi, D.A.; Rezk, H.M.; Aziza, A. and El-Sherbiny, M. (2015) 'Tooth coronal pulp index as a tool for age estimation in Egyptian population', $J$. 
Forensic Sci. Criminol., 2(5), p502 508.

El-Shenawy, R.R.; El-Sayed, M.A.; Hamdy, R.M. and Eid M.H. (20 \ \&) 'Assessment of the development of permanent teeth in a group of Egyptian children at the age of $8-10$ years, a radiographic study', Thesis, Faculty of Oral and Dental Medicine, Cairo University (abstract).

Gustafson, G. (1950) 'Age determination on teeth', J. Am. Dent. Assoc., 41(1), p 4554.

Harris, M.J.P. and Nortje, C.J. (1984) 'The mesial root of the mandibular molar. A possible indicator of age', $J$. Forensic Odontostomatol., 2, p 39-43.

Hassan, N.A. and Abo Hamila, N.A.A. (2007) 'Orthopantomography and age determination using third molar mineralization in a sample of Egyptians'. Mansoura J. Forensic Med. Clin. Toxicol., 25(1), p45-59. DOI:10.21608/MJFMCT.2007.52485

Hassan, N.A. and Sheahb, A.A. (2004) 'Histomorphometric study of dental cementum and correlation of cemental incremental lines with age in Egyptians', Mansoura J. Forensic Med. Clin. Toxicol., 12(2), p 1-25.

Ikeda, N.; Umetsu, K.; Kashimura, S.; et al. (1985) 'Estimation of age from teeth with their soft X-ray findings', J. For. Med., 39, p 244-250.

Jayaraman, J.; King, N.M.; Roberts, G.J. and Wong, H.M. (2011) 'Dental age assessment: Are Demirjian's standards appropriate for southern Chinese children'. J. Forensic Odontostomatol., 29, p 22-28.

Kvaal, S.I.; Kolltveit, K.M.; Thomsen, I.O. and Solheim, T. (1995) 'Age estimation of adults from dental radiographs'. Forensic Sci. Int., 74(3), p175-185.

Mincer H.H.; Harris E.F. and Berryman H.E. (1993) 'The A.B.F.O. study of third molar development and its use as an estimator of chronological age". $J$. Forensic Sci., 38, p 379-390. 10.1520/JFS13418J

Nolla, C.M. (1960) 'The development of permanent teeth', J. Dent. Child, 27, p 254-266.

Panchbhai A.S.. (2011) 'Dental radiographic indicators, a key to age estimation". Dentomaxillofac Radiol., 40, p199-212.

Rabie, R; El-Bakary, A.A.; Elhindawy, M.M. and El Hawary Y.M (2018) 'Age estimation in Egyptian children: Comparison between different methods' Master Thesis in Oral Biology, Faculty of Dentistry, Mansoura University, Egypt.

Schmeling, A.; Olze, A.; Reisinger, W. and Geserick, G. (2004) 'Forensic Age estimation of living people undergoing criminal proceedings". Forensic Sci. Int., 144, p 243-245.

Schour, I. and Massler, M. (1941) 'Development of human dentition'. $J$. Am. Dent. Assoc., 20, p379-427.

Soliman, N.L.; El-Zainy, M.A.; Hassan, R.M. and Aly, R.M. (2011) 'Timing of deciduous teeth emergence in Egyptian children'. Eastern Mediterranean Health Journal, 17 (11), p875-881.

Stavrianos, C.; Mastagas, D.; Stavrianou, I. and Karaiskou, O. (2008) 'Dental age estimation of adults: A review of methods and principles'. Res. J. Med. Sci., 2, p258-268.

Wahdan, A.A.; Lashin, H.I. and Elborae, M.O. (2017) 'Estimation of age using mandibular permanent first molars in 
panoramic radiographs in a sample of Egyptian population'. Mansoura J. Forens. Med. Clin. Toxicol., 25(2), p112.

Willems, G.; Moulin-Romsee, C. and Solheim, T. (2002) 'Non-destructive dental-age calculation methods in adults: intra- and inter-observer effects', Forensic Sci. Int., 126(3), p221-226.
Willems, G.; Van Olmen, A.; Spiessens, B. and Carels, C. (2001) 'Dental age estimation in Belgian children: Demirjian's technique revisited', $J$. Forensic Sciences, 46(4), p893-895. DOI: $10.1520 / J F S 15064 J$

Willems G. (2000) 'Dental age estimation and computers; Proceedings of the European IOFOS Millienium Meeting Leuven', Leuven, Belgium: Forensic Odontology, p161-175. 